\title{
THE
}

\section{Financial Literacy, Portfolio Choice, and Financial Well-Being}

Zhong Chu

Zhengwei Wang

Jing Jian Xiao

University of Rhode Island, jjxiao@uri.edu

Weiqiang Zhang

Follow this and additional works at: https://digitalcommons.uri.edu/hdf_facpubs

The University of Rhode Island Faculty have made this article openly available.

Please let us know how Open Access to this research benefits you.

This is a pre-publication author manuscript of the final, published article.

Terms of Use

This article is made available under the terms and conditions applicable towards Open Access Policy Articles, as set forth in our Terms of Use.

\section{Citation/Publisher Attribution}

Chu, Z., Wang, Z., Xiao, J. J., \& Zhang, W. (2017). Financial literacy, portfolio choice and financial wellbeing. Social Indicators Research, 132(2), 799-820. doi: 10.1007/s11205-016-1309-2

Available at: http://dx.doi.org/10.1007/s11205-016-1309-2

This Article is brought to you for free and open access by the Human Development and Family Science at DigitalCommons@URI. It has been accepted for inclusion in Human Development and Family Science Faculty Publications by an authorized administrator of DigitalCommons@URI. For more information, please contact digitalcommons-group@uri.edu. 
Chu, Z., Wang, Z., Xiao, J. J., \& Zhang, W. (2017). Financial literacy, portfolio choice, and financial well-being. Social Indicators Research, 132(2), 799-820.

\title{
Financial literacy, Portfolio Choice and Financial Well-being
}

Zhong Chu ${ }^{1}$, Zhengwei Wang ${ }^{1}$, Jing Jian Xiao ${ }^{2}$, Weiqiang Zhang ${ }^{1}$

${ }^{1}$ Tsinghua University, ${ }^{2}$ University of Rhode Island

\begin{abstract}
This study examined potential effects of financial literacy on household portfolio choice and investment return, an indicator of financial wellbeing. Using data from the 2014 Chinese Survey of Consumer Finance, financial literacy was measured and further categorized into basic financial literacy and advanced financial literacy. This study tested the hypothesis that financial literacy affects household choice between stock and mutual fund. The results indicated that households with higher financial literacy, especially those with higher level of advanced financial literacy tended to delegate at least part of their portfolio to experts and invest in mutual fund. However, households who were overconfident about their financial literacy tended to invest by themselves and were more likely to hold only stocks in their portfolios. The findings also indicated that households with higher financial literacy had a better chance of receiving a positive investment return, suggesting that higher financial literacy may result in a better financial outcome.
\end{abstract}

\section{Introduction}

Financial products are everywhere in our modern life. The rapid spread of financially complex products is increasingly requiring people to decide how much to save and where to invest and, during retirement, to take on responsibility for careful decumulation so as not to outlive their assets while meeting their needs, which requires households to be well-equipped with financial literacy. However, low financial literacy is found among consumers in many countries (Lusardi \& Mitchell 2014).

There are various literatures linking financial literacy with economic decisions. It has been shown that households with high financial literacy do better in financial and retirement planning (Lusardi \& Mitchell 2005; Lusardi \& Mitchell 2007). Also they perform better in credit card usage and dealing with debt (Disney \& Gathergood 2013; Mottola 2013). There are also evidences showing a strong relationship between 
financial knowledge and the likelihood of engaging in desirable financial practices: paying bills on time, tracking expenses, budgeting, paying credit card bills in full each month, saving out of each paycheck, maintaining an emergency fund, diversifying investments, and setting financial goals (Hilgert et al 2003). Also financial literacy is found to contribute positively to financial satisfaction (Xiao, Chen \& Chen 2014; Ali, Rahman, \& Bakar 2014).

On the other hand, low financial literacy is associated with poor financial decisions in equity investment, debt financing, as well as long term retirement planning and these decisions can lead to decrease in welfare. Individuals with lower level of financial literacy are less likely to participate in stock market (Kimball \& Shumway 2006; Van Rooij et al., 2011; Yoong 2011) and thus can forgo the substantial equity gain (Cocco, Gomes \& Maenhout 2005). Households with lower level of financial literacy can also make suboptimal decisions when choosing loans or mortgages (Lusardi \& Tufano 2008; Utkus \& Young 2011; Moore 2003), and suffer from problems such as debt accumulation (Lusardi \&Tufano 2008), bankruptcy and foreclosure (Gerardi et al. 2010).

Financial literacy has not yet been directly linked to how household choose among different kinds of assets. There are literatures about household financial choices and diversifications, however, using trading data, researchers failed to measure financial literacy accurately (Bailey \& $\mathrm{Ng}$ 2006). In this study, we used data from the 2014 Chinese Survey of Consumer Finance and focused on household's choice between the two risky assets, stock and mutual fund. The survey covered nearly all provinces of China and included questions about household's asset and debt, income and expenditure, financial plans as well as financial literacy. The section of financial literacy in the survey provides opportunities to link financial literacy with other household financial outcomes. The unique contributions of this study are using refined measurements for financial literacy and directly linking financial literacy to household financial decisions. The research results indicate that people with higher financial literacy, especially those who understand advanced financial knowledge well, tend to add mutual funds to their portfolio. Besides, we also propose a definition about the overconfidence in financial literacy. People who are overconfident about financial literacy tend to only invest in stock. Finally, financial literacy is found to be linked to positive portfolio return, an indicator of household financial wellbeing.

This paper is organized as following: in section 2, we present an overview of 
Chinese financial market. In section 3, we provide a review of related literature and present hypotheses. In section 4 , we describe the data and variables. In section 5, we discuss the results. In section 6, we present results of robustness check using an alternative way to calculate financial literacy. In the last section, we conclude with a brief discussion.

\section{Overview of Chinese Financial Market}

China's stock market was established around 1992 and has grown in at a phenomenal pace since then: the number of listed stocks was 13 and the aggregate market capitalization was US\$1.3 billion in 1991 (Eun \& Huang 2007), while the number of listed stocks increased to 2800 and the aggregate market capitalization has risen to more than US\$7 trillion by the end of 2015 (China Securities Regulatory Commission, 2015). However, China has only slowly developed a legal framework for stock markets and has a weak law enforcement record, which played at best a marginal role in China's market development (Pistor \& Xu 2005). There are evidences showing that China's stock markets are not efficient in that prices and investors' behavior are not necessarily driven by fundamental values of listed firms (Allen, Zhang \& Zhao 2012). Morck et al. (2000) found that stock prices are more "synchronous" (stock prices move up and down together) in emerging countries including China than that in developed countries. They attribute this phenomenon to poor investor protection and imperfect regulation in emerging markets. Considering all these factors, it is not an easy job for households to invest in the Chinese stock market.

Mutual funds, as an investment instrument, have been playing a more and more critical role in the Chinese financial market. As the number of the mutual funds in the Chinese financial market grows rapidly, and the types of mutual funds increase as well as the investor demand for diversification. In China, mutual fund companies have become the most important institutional investors, who are not only optimizing the investors' structure in the Chinese security market but also promoting the value investment concept to the public (Zhao \& Wang 2007). However, mutual fund trading is not as easy as stock trading. Some mutual funds can be traded just like stocks while some need to be bought from banks or directly from the mutual fund companies. Therefore, retrieving the information and trading procedures of these mutual funds are much more time-costing than stocks.

Almost all (98.9\%) households reported ownership of some financial assets in 
China (Liao, Huang \& Yao, 2010). Stocks and mutual funds are most held among risky financial assets (Gan 2013). In this study, stock refers to the shares of listed company which can be traded in the two stock exchanges (the Shanghai and Shenzhen stock exchanges) and mutual fund refers only to public offering mutual funds, such as the mutual funds sold by commercial banks and mutual fund companies. Different from financial markets in developed countries, the financial advising industry in China is not well developed. Financial advice providers such as private banks offer services to households with more than USD 1 million of investable assets, which means only households that are extremely wealthy can obtain professional advice (Wang et al. 2014). Therefore, we regard financial literacy as an important factor when we discuss Chinese household's portfolio choice and their financial wellbeing, due to the lack of support from financial service professionals. Also, this gives us the opportunity to explore the net effect of financial literacy without worrying about the potential compounding effect of financial advising service.

Most existing studies on financial literacy using data from the United States and other European countries (Puri \& Robinson 2007; Christelis, Jappelli, \& Padula 2010; Van Rooij et al. 2011). Because China is a large, emerging economy, it is important to study the role of financial literacy in how Chinese households invest in risky assets. China's aggregate household saving rate is among the highest in the world (Wang \& Wen 2012). And the long tradition of "stay in the middle" that tells one to stay from extreme and proverbs such as "One misstep could cause a thousand year disaster" shape the culture of Chinese households to avoid risk. However, there are also research findings showing that the Chinese are more risk tolerant than Americans in their financial decisions which may also due to culture reasons (Fan \& Xiao 2006; Weber \& Hsee 1998). Therefore, the culture difference may affect financial decisions of Chinese households.

\section{Prior Research and Hypotheses}

Traditional consumption theories such as the life cycle hypothesis (Modigliani \& Brumberg 1954) and permanent income hypothesis (Friedman 1957) assume that individuals have the capacity to undertake complex economic calculations and to have expertise in dealing with financial markets (Lusardi \& Mitchell 2014). Lusardi, Michaud and Mitchell (2013) construct a multi-period dynamic life cycle model where individuals not only select capital market investments, but also undertake investments in financial knowledge and people would pay a certain amount to obtain 
more financial knowledge. Their conceptual model suggests that higher financial literacy is associated with better investment portfolio choices and outcomes.

\section{Choice between Stock and Mutual Fund Investing}

Consumers with low financial literacy may seek financial advice in investment. Financial advising plays an important role here. For people that are not good at dealing with complex financial products, they can turn to financial advisors for help. Financial institutions could provide products and processes to improve the financial wellbeing of their customers (Vlaev \& Elliott 2013). A substitute for financial advice, although not a perfect one, is mutual fund. Households can pay a fee and delegate part of their portfolio to mutual fund managers, who are well educated in finance, and usually have rich experience of investing in a specific field. Research literatures show that mutual fund managers do a good job in both stock selection (Elton, Gruber \& Blake 1996; Daniel et al 1997; Carhart 1997) and timing ability (Jiang, Yao \& Yu 2007; Kaplan \& Sensoy 2008; Elton, Gruber \& Blake 2012). As for mutual fund performance, it has been documented that risk adjusted returns of mutual fund, net of fees and expenses are comparable to returns of the market return (Ippolito 1989), and the vast majority $(80 \%)$ of active managers having at least enough skills to cover their fees (Berk \& Green 2004).

Without the help of professional financial adviser, how do households with different levels of financial literacy make their portfolio decisions? First, we considered the participation problem. According to the financial theory, even households with relatively low risk tolerance should participate, to some degree, directly or indirectly, in the stock market (Campbell 2006). However, many families have failed to participate in risky asset market. One explanation is that different households have different preferences about risk or uncertainty, some are extremely loss avert and resist to participate (Barberis, Huang, \& Thaler 2006). Ambiguity aversion could also lead to under-participation (Dimmock, Kouwenberg, Mitchell, \& Peijnenburg 2013). Another explanation is that investors have different expectations about the future return of stocks, in which some believe their risk adjusted return is just below zero. Hurd, Van Rooij and Winter (2011) find that expectations do affect household stock market participation. Those who are more optimistic are more likely to participate in stock market (Puri \& Robinson 2007). Moreover, another popular explanation is that families fail to join the stock market because they are presented with fixed cost (Vissing-Jørgensen 2004). The costs include monetary cost and 
information cost, and a household makes the decision to participate based on the tradeoff between the cost and return. And therefore, factors that could change the participation cost could also influence household participation choice. Monetary cost usually includes income and wealth (Calvet, Campbell \& Sodini 2007). For information cost, several factors are considered to be linked with the participation puzzle: cognitive ability (Christelis, Jappelli, \& Padula 2010; Grinblatt, Keloharju, \& Linnainmaa 2011; Agarwal, \& Mazumder 2013), awareness of stocks (Guiso \& Jappelli 2005), education level (Cole, Paulson, \& Shastry 2014) and social interactions (Hong et al. 2004). Background risk can be another factor that influences risky asset participation. Heaton and Lucas (2000) find that background risks from sources such as entrepreneurial income influence portfolio allocations. Age and home ownership are also related background risk factors and thus influence participation (Cardak, \& Wilkins 2009). Household financial literacy may be considered as another background risk factor.

\section{Financial Literacy and Portfolio Choice}

In this study, we focused on the role of financial literacy in consumer decisions on choosing stock or mutual fund, which are the two most popular risky assets in China. As mentioned in the Section 2, under the background of Chinese financial markets, financial advising service is rare and therefore financial literacy plays an important role here. We propose two competing hypotheses below:

$\mathrm{H}_{1 \mathrm{a}}$ : Households with higher financial literacy are more likely to invest in stocks directly.

$\mathrm{H}_{1 \mathrm{~b}}$ : Households with higher level of financial literacy are more likely to delegate part of their portfolios to fund managers and invest in mutual funds.

$\mathrm{H}_{1 \mathrm{a}}$ is justified because that they have confidence in their own financial knowledge and the trading cost of direct stock investing are much lower than investing in mutual fund. The competing hypothesis is based on the saying that the more wit, the less courage. Investing in risky assets is a complex task, and people who know less about the potential risk could be more aggressive and do direct stock investment, which is also much easier than mutual fund trading in Chinese financial markets. However, people who are equipped with more financial knowledge are more careful about direct investment since they know that compared to stock, mutual fund is more diversified in the first place. Also, regulations and rules in China require mutual fund managers to fully diversify their portfolios. And thus people with high 
level of financial literacy choose to delegate part of their money to mutual funds, to give more diversification to the portfolio and earn profit from experts managed investment, although they have to pay extra management fees.

There are mixed evidences from the research literature. The $\mathrm{H}_{1 \mathrm{a}}$ is supported by several studies. Korniotis and Kumar (2013) find that "smart" investor possess more related information and tend to hold concentrated portfolios with only a handful of stocks. Bailey and $\mathrm{Ng}$ (2006) find that investors who are smarter or are with stronger behavioral biases, a preference for gambling, or residence in states where lotteries are popular, tend to choose stock. Alessie, Hochguertel and Soest (2004) conclude that mutual fund is particularly attractive for investors with little financial knowledge.

However, Gaudecker (2015) finds that people with below-median financial literacy trust their own decision-making capabilities and lose an expected 50 basis points $(0.5 \%)$ on average. And this finding supports $\mathrm{H}_{1 \mathrm{~b}}$ that people with high level of financial literacy choose to delegate part of their money to mutual funds and household with little knowledge choose to invest on their own. Van Rooij et al. (2011) show that those who display high levels of financial literacy are more likely to rely on formal sources such as newspapers, financial advisors, and the internet. Therefore, if mutual fund acts as the substitute of financial advice, we can infer that households with high level of financial literacy will choose to invest in mutual fund, which supports $\mathrm{H}_{1 \mathrm{~b}}$.

\section{Financial Literacy Overconfidence and Portfolio Choice}

In this study, we also examined whether financial literacy overconfidence affects household portfolio choice. The financial literacy overconfidence is defined based on the difference between perceived financial literacy and subjective financial literacy. And this is a supplement for the first and main topic which discusses the financial literacy and portfolio choice. Overconfidence has been linked with over trading in stock market (Barber \& Odean 2001; Grinblatt \& Keloharju 2009). However, its relationship with portfolio choice between stock and mutual fund has not been fully addressed. Bailey and $\mathrm{Ng}$ (2006) find that unsophisticated investors who have an illusion of control, which may be generated by overconfidence, prefer individual stocks. Also there is evidence that financial literacy overconfidence is correlated with higher possibility of stock market participation (Xia, Wang \& Li 2014). We therefore propose the following hypothesis:

$\mathrm{H}_{2}$ : Overconfident consumers are more likely to hold stocks instead of mutual 
funds.

\section{Financial Literacy and Investment Return}

We also took financial wellbeing into consideration in this study. Financial wellbeing has been defined in various way, such as retirement planning (Lusardi \& Mitchell 2005), financial management (Lusardi \& Mitchell 2007; Vlaev \& Elliott 2013), capability of dealing with debt (Tsai, Dwyer \& Tsay 2014) and financial satisfaction (Ali, Rahman, \& Bakar 2014; Xiao, Chen \& Chen 2014). In this study, we consider the household portfolio performance as an indicator of financial wellbeing, which is also the result of household portfolio choice. There are inconsistent results in literatures about how financial literacy could affect household portfolio performance. Calvet, Campbell and Sodini (2007) find that financially sophisticated households invest more aggressively, and overall they incur higher return losses from under-diversification. However, Gaudecker (2015) shows that nearly all households that score high on financial literacy achieve reasonable investment outcomes. In Korniotis and Kumar (2013), results indicate that "smart investors," who are more financial sophisticated outperform dumb investors by about 3\% annually on a risk-adjusted basis. As it is discussed in Section 2, Chinese stock market has suffered from great variation, and financial literacy may play an important role in household portfolio performance. And similar to other kind of financial wellbeing, we propose a hypothesis as follows:

$\mathrm{H}_{3}$ : Financial literacy is positively associated with positive return of the household investment portfolio.

\section{Methodology}

\section{Data}

We used data from the 2014 Chinese Survey of Consumer Finance sponsored by China Center for Financial Research and carried out by the Institute of Social Science Survey (ISSS). The survey covers nearly all the provinces of mainland China and includes questions about household's asset and debt, income and expenditure, financial plans as well as financial literacy. The survey included 3,906 households living in 25 provinces of mainland China, except for Xinjiang, Tibet, Qinghai, Inner Mongolia, Ningxia, and Hainan. Designed by an interdisciplinary group of scholars, the survey collected a sample representative of the national population. The survey covers $1 \%$ of the nation's total population, selected by a stratified multi-stage clustering sampling method from the Population Census, with the strata set at the 
provincial level and the ultimate sampling unit set at the residential community level. (Gao, Wu \& Zhai 2014; Li \& Wu 2014). More details of the survey and data are described in Xie and $\mathrm{Hu}(2014)$.

\section{Measures of Financial Literacy}

Financial literacy was measured with information from the answers to 12 questions about some financial knowledge. And the specific questions are included in the appendix.

The twelve questions were further divided into two categories following Van Rooij, Lusardi and Alessie (2011). One set of questions is about basic financial knowledge where no questions are about the stock market, stocks, and bonds. The other set of questions are about more advanced financial knowledge as well as knowledge related to stocks, the stock market, and other financial instruments. The survey questions measuring financial literacy in the 2014 Chinese Survey of Consumer Finance are very similar to those used in Van Rooij, Lusardi and Alessie (2011) except for the question about the central bank. The first seven questions were used to measure basic financial literacy and the last five questions measured advanced financial knowledge. In data analyses, we used several variables to measure household financial literacy. We first introduced a general measure of financial literacy (variable $F L$ ), represented by the total number of correct answers out of the twelve questions. Then we created two refined measures of financial literacy, Financial_basic and Financial_adv. Financial_basic measures the basic knowledge, represented by the right answers out of the first seven questions, while Financial_adv measures the advance knowledge, represented by the right answers out of the last five questions.

\section{(Insert Figure 1 here)}

Figure 1 reports the proportion of households providing correct, incorrect, and "do not know" answers to each of the twelve basic literacy questions. According to Figure 1, the households in the sample have good grasp of common financial questions, such as high return is accompanied by high risk and money has time value, in which $85 \%$ of respondents provide the right answer to the relationship between risk and return and $68 \%$ of respondents knows money today is more worthy than the same amount of money next year. However, when it comes to questions like "the risk of stock" and "the meaning of holding stocks," the percentages of correct answers dropped sharply and the percentages of "do not know" reply increased. Only $13 \%$ 
households answered the question about mutual fund correctly, while $16 \%$ knew what the rights and responsibilities of holding stocks are. $42 \%$ household could not compare the risk between mutual fund mainly investing in stock and those mainly investing in bond.

For financial literacy variables, the mean of variable $F L$ is 5.49 . Only $1 \%$ respondents get all 12 questions right, while $5.61 \%$ of all respondents give wrong answers to all 12 questions. For the basic knowledge part, the maximum value of financial_basic is 7, and the mean value is 3.90. For advance knowledge part, the maximum value of financial_adv is 5, while the mean value is 1.59 .

\section{Financial Asset Holding Variables}

In this study, we focused on stock and mutual fund holdings in household portfolios. We used the dummy variable stock_holding to indicate whether a household holds stocks and used fund_holding to indicate mutual fund holding. And we used pariticipation to indicate whether a family holds stock, mutual fund, or both, which represents whether the household participates in the financial market.

\section{(Insert Table 1 here)}

The summary statistics of these variables are presented in Table 1. Only $13.4 \%$ households held stocks and/or mutual funds, and about $10 \%$ held stocks. For mutual fund holding, the percentage (5.5\%) is just about half of stock holding. And these rates are very close to those reported by Gan (2013) who used another national survey of consumer finance in China. Therefore, there is participation puzzle (Haliassos \& Bertaut 1995) in the China stock market, since the participation rate is relatively low. Also, it seems that stock is more popular than mutual fund among Chinese households.

\section{Control Variables}

In this study, we also included several control variables, which according to the literatures, may affect portfolio decisions. Age may affect household participation choice in two aspects. On the one hand, age may affect cognitive ability which has been shown to affect household financial decision making (Christelis, Jappelli, \& Padula 2010; Grinblatt, Keloharju, \& Linnainmaa 2011; Agarwal, \& Mazumder 2013). On the other hand, the elderly are faced with more health problems and therefore have higher background risk which affect family's participation in risky asset (Cardak, \& Wilkins 2009). Also, the square of age is included due to the life cycle hypothesis, which is also related to the asset allocation decision. In the dataset, the age variable 
refers to the age of the family member who answers financial literacy questions. And the family member is supposed to be responsible for household investment decision.

We also included gender. According to Lusardi and Mitchell (2008) gender differences are found in long-term financial planning. Also males are more prone to participate in risky investment due to overconfidence (Barber \& Odean, 2001). The gender variable is a dummy one, 1 represents male, 0 female. $45 \%$ of the respondents are male. Similar with age, the gender variable refers to the gender of the family member who answers the financial literacy questions. The average value of the age variable is 50.42 .

We also included income and business owning status to control for the background risk (Heaton \& Lucas 2000). The income variable represents the income of the household in the last 12 months. The mean value of income 71867.35 renminbi yuan. The natural logarithm value of income was used in the analyses. The business owner variable is a dummy one, 1 means there are family members who own a business. $13 \%$ of the households have their own businesses. We also included housing condition variable that may affect household background risk. There are four types of living conditions: own or partial own the house, special house provided by the government, rent the current house or other types. We included dummy variables for these types and control for the potential background risk.

Risk attitude may affect household portfolio choice (Vissing-Jørgensen \& Attanasio 2003; Barberis, Huang \& Thaler 2006), and we included the risk attitude variable as a control variable. The higher the value, the more risk averse the household is. If the value is 1 , the respondent prefers products of both high risk and high return. If the value is 4 , the respondent is extremely risk averse and would not like to take any risk at all. $45 \%$ of the respondents would not like to take any risk at all, and the mean value of the risk attitude is 3 .

We also included family size, which negatively affects the average income per family member (Chen \& Yang 2015) and thus could affect household portfolio choice. The mean value of the family size is 3.20 . Besides we also included marriage status following previous research on risky asset participation (Xia, Wang \& Li 2014; Grinblatt, Keloharju, \& Linnainmaa 2011). The variable marriage is a dummy variable, where 1 represents the respondent is married.

\section{Empirical Strategy}

We proposed two competing hypotheses. One hypothesis is that people with 
higher financial literacy are more likely to choose to invest by themselves and invest in stock directly. The other is "the more wit, the less courage" hypothesis: household with higher level of financial literacy are more likely to choose to delegate at least part of their money to mutual funds.

In the model proposed by Georgarakos and Inderst (2011), the process of household decision making is generalized into a two steps game: people first decide whether to participate in financial market and then decide how to choose between two risky assets. It is assumed that for a given investor both products can be equally suitable, though actually only one provides the best "fit." The expected utility from a suitable product is denoted by $\mathrm{U}_{\mathrm{h}}$, that from a non-suitable product by the strictly lower utility $\mathrm{U}_{1}$. The investor's expected utility from choosing the safe and less complex product is denoted by $\mathrm{U}_{0}$. Since the authors solve the game backwards, the second step is considered first. Investors with different levels of perceived financial literacy have different distributions of posterior belief and thus have distinct probabilities of choosing a certain asset in the second step. The investor then compares the expected utility $(\mathrm{U} *)$ of the second step with $\mathrm{U}_{0}$, and will only participate if the expected utility is larger than $\mathrm{U}_{0}$. It can be derived from the model that $\mathrm{U} *-\mathrm{U}_{0}$ are larger when perceived financial capability is higher. And thus perceived financial literacy influences both steps.

We followed the approach of Georgarakos and Inderst (2011). However we used objective financial literacy rather than the perceived financial literacy here. There are two reasons we used objective financial literacy here. First of all, objective financial literacy is more accurately measured in the survey. The choice of the households concentrated in the middle level (average level of financial literacy or below average) which may not accurately reflect the true level of financial literacy, and this may be due to the tradition of Chinese to choose to "stay in the middle". Second, most financial literacy studies use objective financial literacy if they use survey data as it is in this research (Hung, Parker \& Yoong 2009; Hastings, Madrian \& Skimmyhorn 2013). And we will discuss the perceived financial literacy in the next session.

For the first step, we considered the two risky assets; stock and mutual fund as a whole, and included the financial literacy variable and controls for other related factors. And it can be modeled by equation (1).

$$
\operatorname{Pr}\left(\text { Participation }_{h}=1\right)=\alpha+\beta \text { financialliteracy }{ }_{h}+Z_{h}{ }^{\prime} \delta_{0}+\varepsilon_{h} \text { (1) }
$$

Where " $h$ " represents the index of the household. The way we measured financial 
literacy has been discussed in section 3. And $Z_{h}$ represents the vector of demographic characters. $\varepsilon_{h}$ is the error term. We use $\varnothing\left(\alpha+\beta\right.$ financialliteracy $\left._{h}+Z_{h}{ }^{\prime} \delta_{0}\right)$ to represent the chance that household participate in financial market.

For the second step, households decide which asset they want to buy, stock or mutual fund. And we used equation (2) to estimate how different factors affect the choice between stock and fund.

$\operatorname{Pr}\left(\right.$ fund_holding $h \mid$ Participation $\left._{h}=1\right)=\alpha_{f}+\beta_{f}$ financialliteracy $_{h}+Z_{h}{ }^{\prime} \delta_{0}+\varepsilon_{h}$

We used Probit model to estimate equation (1) and (2) in empirical test. The link between the two equations is that, for equation (1), all households are included, while only households who choose to participate in equation (1) are considered in equation (2). And the reason we do this is that only households who choose to participate in the first step can actually choose between the two assets.

If the hypothesis that people with high financial literacy choose to invest by themselves and invest in stock directly is right, the coefficient $\beta_{f}$ should be negative, since household with higher financial literacy simply want to invest all by themselves and not delegate it to others. And they would not like to invest in mutual fund. If the opposite is true, $\beta_{f}$ should be positive.

\section{Results}

\section{Financial Literacy and Market Participation}

We estimated equation (1) using the Probit model. We used two sets of measures of financial literacy. The first set includes $F L$ that was to measure financial literacy as a whole. And the second set included financial_basic and financial_adv that measure basic financial knowledge and advance financial knowledge, respectively. The results are shown in Table 2.

\section{(Insert Table 2 here)}

In column (1) and (3) of Table 2, we used the $F L$ measure of financial literacy and column (2) and (4) financial_basic and financial_adv. First, we did not include control variables. The results in column (1) and (2) indicate that, financial literacy, in both two sets of measurements is significantly associated with financial market participation. After control variables were entered, the coefficients and significance levels of financial literacy variables are nearly unchanged. Van Rooij, Lusardi and Alessie (2011) find that households with higher financial literacy are more likely to participate. And the regression results are consistent with the previous study. In 
addition, age has a $U$ shape effect on participation, the coefficient of age is positive and significant, while the coefficient of age square is negative and significant. This implies that as age increases investors participate more, however, when it comes to a certain point (for column (3) 59 years old and 60 for column (4)), the probability of participation drops. This $U$ shape effect may be the combine effect of age on cognitive ability and background risk. Most Chinese workers retire at the age of sixty, some face great decline of income. And the probability of getting a disease is higher than the younger workers. The cognitive ability can also decay due to aging. All these factors can affect household market participation. Self-employed respondents are less likely to participate in the financial market. And this may be due to the fact that they have already face great risk. According to the result, risk aversion is also associated with participation (the coefficient is negative significant), the more risk averse, the less likely to participate. And this result is consistent with Calvet, Campbell and Sodini (2007).

\section{Financial Literacy and Portfolio Choice}

We also tested the two hypotheses by estimating equation (2). And the result is presented in Table 3. The results of the first column indicate that households with general high financial literacy are more likely to choose mutual fund when they make their portfolio choice. While when we turned to the result in column (2), in which we separated financial literacy into two parts, we found that only advanced financial literacy was associated with mutual fund holding. And the coefficient is larger than that of general financial literacy $(F L)$. This means that getting one more question right in advance financial knowledge section has twice the effect of getting one more question right in the general financial literacy section on the participation of mutual fund. The results suggest that we should reject the hypothesis that people with high financial literacy just choose to invest by themselves and invest in stock directly, because the estimation of the financial literacy coefficient is positive and significant in both the two sets of measurements. And this means that the famous saying "the more wit, the less courage" also works here. Also, advanced financial literacy corresponds to questions about risk and financial market, which implies that households who understand the market and risk well are more prone to invest in mutual fund. We also found that the coefficient of gender is negative and significant. And this indicates that males are less likely to invest in mutual fund and are more likely to invest only in stock, consistent with previous research in which males are 
more likely than females to have behavior bias due to overconfidence (Barber \& Odean, 2001). Besides, the coefficient of risk attitude is positive and significant, which suggests more risk averse households would tend to invest in mutual fund, matching the diversification function of mutual fund.

(Insert Table 3 here)

\section{Confidence or Overconfidence}

In this section, we provide an explanation to the question that if households with higher financial literacy tend not to invest in stocks, what are other households that do it? Georgarakos and Inderst (2011) argue that investors use the perceived financial literacy to make financial decision. In the survey used in this study, there are five levels of perceived financial literacy for the respondents to choose, from level 1 to level 5, and level 1 means the respondent thinks her/his level of financial literacy is far beyond average, and level 5 represents far below average. And the distribution of the answers is listed in Table 4.

\section{(Insert Table 4 here)}

We first used equation (1) and (2) to test the effect of perceived financial literacy. The results are listed in Table 5. In column (1) and (2), the results indicate perceived financial literacy may affect participation while the effect on the portfolio choice is insignificant. We then used a dummy variable to represent whether the respondent thinks he or she has above average financial literacy. And the result in column (3) and (4) are similar to (1) and (2). Therefore, using this data set we cannot verify that if perceived financial literacy affect how households choose between the two different financial assets.

To further examine the issue, we used a measure of financial literacy overconfidence following Xia, Wang \& Li (2014):

(1) Respondents who think their financial knowledge is at average level or above.

(2) Respondents whose actual financial literacy (measured by FL) is below the average level (7.7).

The two criteria should be both satisfied to be recognized as overconfidence. We then used the overconfidence dummy variable to estimate whether overconfidence affects portfolio choice. And the dependent variable is a dummy variable indicates whether the households only invest in stock. And the regression result is shown in column (5) of Table 5. 


\section{(Insert Table 5 here)}

The regression result shows that households who are overconfident about their financial knowledge are more likely to hold stock in their portfolio. Furthermore, this can be interpreted as that consumers who are overconfident in financial literacy choose to pick stocks by themselves rather than by some mutual fund managers. Therefore, it is not those who perceive to have high level of financial literacy are investing only in stock, but those who overestimate their financial literacy levels.

\section{Financial Literacy and Portfolio Return}

Next, we went to further by testing whether households with higher financial literacy actually do better in investment. It is the portfolio performance that really matters for financial wellbeing. We used a dummy variable positive_return to indicate whether households make a profit in investment. We used Probit model similar to equation (2), and only change the dependent variable into positive return dummy. The result is shown in Table 6.

\section{(Insert Table 6 here)}

We found that households with higher advance financial literacy tended to receive positive return. And this suggests that financial literacy may contribute to good financial performance. However, the effect of general financial literacy are not significant, which suggests that advance financial literacy which concentrates more on the understanding of risky assets matters more for a better portfolio performance. The coefficient of basic financial literacy $(-0.103)$ is negative, which is a little bit counterintuitive. One possible reason may be that the score of basic financial literacy concentrated in 5, 6 and $7(72.8 \%)$. Lack of variation could bring errors to the estimation of the coefficient. We therefore constructed a dummy variable for above median basic financial literacy (the median of all the risky asset participants is 5), and did the estimation again and the results are shown in the column (3) of Table 6. The coefficient of basic financial literacy is not significant while the coefficient of advance financial literacy is still positive and significant.

\section{Robustness Check and Further Discussion}

The method of measuring the financial literacy used in this study has been also used in other studies in the financial literacy literature. Lusardi and Mitchell (2005) and Van Rooij, Lusardi and Alessie (2011) used the method of factor analysis to construct two financial literacy indices. For robustness check, we did it similarly and constructed two indices, factor_basic and factor_adv. Factor_basic was built on 
question 1 to 7, and factor_adv was built on the answers to question 8-12. The higher the factor is the higher financial literacy indicates.

We used the two indices to replace our financial literacy variables and estimated the equations again. And the results are shown in Table 7. The results are nearly unchanged comparing to the previous empirical results. We found that advance financial literacy still have significant and positive influence on mutual fund participation. And our conclusion is not changed.

\section{(Insert Table 7 here)}

Considering the fact that household who have extremely high income have the possibility to hire a financial advisor, which may have different financial behaviors from our assumption. We therefore doing all the estimation again by excluded the top $5 \%$ household who have relatively high income. And the result is shown in Table 8. And the coefficient and significance are nearly unchanged.

\section{(Insert Table 8 here)}

\section{Conclusion}

In this study, we have examined whether financial literacy has potential effects on the portfolio choice of households, especially the choice between the two risky assets, stock and mutual fund. We have also examined if financial literacy has potential to contribute to household financial wellbeing, which in this study refers to positive investment return. Using a Chinese national survey data, we find that households who have high level of financial literacy are more likely to participate in financial markets, which is consistent with previous studies (Kimball \& Shumway 2006; Van Rooij et al. 2011; Yoong 2011). This results indicate that in the context of Chinese financial market, there is still correlation between financial literacy and risky asset investing behavior. Furthermore, we find that households with higher level of financial literacy are more likely to hold mutual fund in their portfolio. Just as the saying the more wit, the less courage, household who have higher level of financial literacy are more careful about direct investment. Additionally, households with higher financial literacy are more likely to earn positive return, which suggests that they actually do better. We also find that overconfident households are more likely to invest only in stocks instead of diversifying by investing in mutual funds.

There are mixed evidences in the literatures about the effects of financial literacy on choice between risky assets and portfolio performance. We used data from China where financial advising service is rare, and we therefore could remove the potential 
compounding effect of the financial advisors when investigating the effect of financial literacy. Although we use Chinese household data, however, the results may also hold in other countries, because "the more wit, the less courage" is an American saying there similar to a proverb in the Chinese culture. Our results about overconfidence complement the previous research on the link between overconfidence and financial behaviors and go further by studying the choice problem.

Previous research on financial literacy usually focuses on its potential effects on market participation, however, little research is done on its potential effects on financial outcomes. This study has filled in this research gap. Only 10\% of household in this survey participate into stock market, while the percentage is even smaller for mutual fund participation, which is only $5 \%$. For those who participate, less than one in four can receive positive return. Meanwhile financial literacy may improve the chance of "winning" in financial market. As we have mentioned in section 2, Chinese financial market is not efficient enough, our research results indicate that investors have a big chance to suffer loss if not equipped with enough level of financial literacy. The results may also holds in other financial markets which are not efficient enough. With the fast development of global financial market, more and more households start to participate in risky financial markets. However, some are not well equipped with financial knowledge. And our results show the importance of increasing household financial literacy, which may help consumers make wise decisions in portfolio choices and improve financial wellbeing. Although effects of current financial education programs are in debate, financial literacy itself should be paid more attention by governments and financial service businesses. Financial literacy has been brought into sight for the last two decades and some developed countries like United States and United Kingdom have introduced financial education programs at various levels. Developing countries like China with a growing financial market could learn successes and lessons experienced by them.

\section{References}

Agarwal, S., \& Mazumder, B. (2013). Cognitive abilities and household financial decision making. American Economic Journal: Applied Economics, 5(1), 193-207.

Ali, A., Rahman, M. S. A., \& Bakar, A. (2014). Financial satisfaction and the influence of financial literacy in Malaysia. Social Indicators Research, 120(1), $137-156$. 
Alessie, R., Hochguertel, S., \& Soest, A. Van. (2004). Ownership of stocks and mutual funds: A panel data analysis. Review of Economics and Statistics, 86(3), 783-796.

Allen, F., Zhang, C., \& Zhao, M. (2012). China's Financial System: Opportunities and Challenges. In Capitalizing China (pp. 63-143). University of Chicago

Press.

Atkinson, A., \& Messy, F. (2012). Measuring financial literacy: Results of the OECD /International Network on Financial Education (INFE) pilot study, OECD Working Papers on Finance, Insurance and Private Pensions, 15. Paris: OECD Publishing.

Bailey, W., Kumar, A., \& Ng, D. (2006). Why do individual investors hold stocks and high expense funds instead of index funds? Johnson Graduate School of Management, Cornell University, Working Paper.

Barber, B. M., \& Odean, T. (2001). Boys will be boys: Gender, overconfidence, and common stock investment. The Quarterly Journal of Economics, 116(1), 261292.

Barberis, N., Huang, M., \& Thaler, R. H. (2006). Individual preferences, monetary gambles, and stock market participation: A case for narrow framing. The American Economic Review, 96(4), 1069-1090.

Berk, J. B., \& Green, R. C. (2004). Mutual fund flows and performance in rational markets. Journal of Political Economy, 112(6), 1269-1295.

Calvet, L. E., Campbell, J. Y., \& Sodini, P. (2007). Down or out: assessing the welfare costs of household investment mistakes. Journal of Political Economy, 115(5), $707-747$

Campbell, J. Y. (2006). Household finance. Journal of Finance, 61(4), 1553-1604.

Cardak, B. A., \& Wilkins, R. (2009). The determinants of household risky asset holdings: Australian evidence on background risk and other factors. Journal of Banking \& Finance, 33(5), 850-860.

Carhart, M. (1997). On persistence in mutual fund performance, Journal of Finance $52,57-82$.

Chen, J., \& Yang, H. (2015). Geographical Mobility, Income, Life Satisfaction and Family Size Preferences: An Empirical Study on Rural Households in Shaanxi and Henan Provinces in China. Social Indicators Research. http://doi.org/10.1007/s11205-015-1102-7 
China Securities Regulatory Commission (2015). Securities market statistics in October 2015. Available at http://www.csrc.gov.cn/pub/csrc_en/marketdata/security/monthly/201511/t20151 124_287067.html

Christelis, D., Jappelli, T., \& Padula, M. (2010). Cognitive abilities and portfolio choice. European Economic Review, 54(1), 18-38.

Cocco, J. F., Gomes, F. J., \& Maenhout, P. J. (2005). Consumption and portfolio choice over the life cycle. Review of financial Studies, 18(2), 491-533.

Cole, S., Paulson, A., \& Shastry, G. K. (2014). Smart money? The effect of education on financial outcomes. The Review of Financial Studies, 27, 2022-2051.

Daniel, K., Grinblatt, M., Titman, S., and Wermers, R. (1997) Measuring mutual fund performance with characteristic-based benchmarks, Journal of Finance, 52, $1035-1058$.

Dimmock, S.G., Kouwenberg, R., Mitchell, O.S., Peijnenburg, K. (2013). Ambiguity aversion and household portfolio choice: empirical evidence. NBER Working paper, 18743, National Bureau of Economic Research.

Disney, R., \& Gathergood, J. (2013). Financial literacy and consumer credit portfolios. Journal of Banking and Finance, 37(7), 2246-2254.

Elton, E. J., Gruber, M. J., \& Blake, C. R. (1996). The persistence of risk-adjusted mutual fund performance, Journal of Business, 69, 133-157.

Elton, E. J., Gruber, M. J., \& Blake, C. R. (2012). An examination of mutual fund timing ability using monthly holdings data. Review of Finance, 16(3), 619-645.

Eun, C. S., \& Huang, W. (2007). Asset pricing in China's domestic stock markets: Is there a logic? Pacific Basin Finance Journal, 15(5), 452-480.

Fan, J. X., \& Xiao, J. J. (2006). Cross-cultural differences in risk tolerance: a comparison between Chinese and Americans. Journal of Personal Finance, 5(3), 54-75.

Friedman, M. (1957). A theory of the consumption function: A study by the National Bureau of Economic Research. Princeton University Press.

Gan, L. (2013). Financial Market Participation. In L.Gan, Z.Yin, N.Jia, S.Xu, S.Ma, \& L.L. Zheng (Eds.), Data you need to know about China: Research Report of China Household Finance Survey (pp. 95-99). Verlag Berlin Heidelberg: Springer Science \& Business Media.

Gao, Q., Wu, S., \& Zhai, F. (2014). Welfare Participation and Time Use in China. 
Social Indicators Research, 124(3), 863-887.

Gaudecker, H.-M. Von. (2015). How does household portfolio diversification vary with financial literacy and financial advice? The Journal of Finance, 70(2), 489507.

Georgarakos, D., \& Inderst, R. (2011). Financial advice and stock market participation. University of Frankfurt.

Gerardi, K., Goette, L., \& Meier, S. (2010). Financial literacy and subprime mortgage delinquency: Evidence from a survey matched to administrative data. Working paper no. 2010-10, Federal Reserve Bank of Atlanta

Grinblatt, M., \& Keloharju, M. (2009). Sensation seeking, overconfidence, and trading activity. Journal of Finance, 64(2), 549-578

Grinblatt, M., Keloharju, M., \& Linnainmaa, J. (2011). IQ and stock market participation. Journal of Finance, 66(6), 2121-2164.

Gruber, M. J. (1996) Another puzzle: The growth in actively managed mutual funds, Journal of Finance, 51, 783-810.

Guiso, L., \& Jappelli, T. (2005). Awareness and stock market participation. Review of Finance, 9(4), 537-567.

Haliassos, M., \& Bertaut, C. C. (1995). Why do so few hold stocks? Economic Journal, 105, 1110-1129.

Hastings, J. S., Madrian, B. C., \& Skimmyhorn, W. L. (2013). Financial literacy, financial education, and economic outcomes. Annual Review of Economics, 5(1), $347-373$.

Heaton, J., \& Lucas, D. (2000). Portfolio choice and asset prices: The importance of entrepreneurial risk. The Journal of Finance, 55(3), 1163-1198.

Hilgert, M. A., Hogarth, J. M., \& Beverly, S. G. (2003). Household financial management: The connection between knowledge and behavior. Federal Reserve Bulletin, 89(7), 309-322.

Hong, H., Kubik, J. D., \& Stein, J. C. (2004). Social interaction and stock market participation. The Journal of Finance, 59(1), 137-163.

Hung, A., Parker, A. M., \& Yoong, J. (2009). Defining and measuring financial literacy. SSRN Electronic Journal. http://doi.org/10.2139/ssrn.1498674

Hurd, M., van Rooij, M., \& Winter, J. (2011). Stock market expectations of Dutch households. Journal of Applied Econometrics, 26(3), 416-436.

Ippolito, R. A. (1989). Efficiency with costly information: A study of mutual fund 
performance, 1965-1984. The Quarterly Journal of Economics, 104(1), 1-23.

Jiang, G., Yao, T., and Yu, T. (2007) Do mutual funds time the market? Evidence from holdings data, Journal of Financial Economics, 88, 119-145.

Kaplan, S. N. and Sensoy, B. A. (2008) Do mutual funds time their benchmarks? Working paper, University of Chicago.

Kimball, M., \& Shumway, T. (2006). Investor sophistication, and the participation, home bias, diversification, and employer stock puzzles. Unpublished manuscript, University of Michigan, Ann Arbor.

Korniotis, G. M., \& Kumar, A. (2013). Do portfolio distortions reflect superior information or psychological biases? Journal of Financial and Quantitative Analysis, 48(01), 1-45.

Li, L., \& Wu, X. (2014). Housing price and entrepreneurship in China. Journal of Comparative Economics, 42(2), 436-449.

Liao, L., Huang, N., \& Yao, R. (2010). Family finances in urban china: Evidence from a national survey. Journal of Family and Economic Issues, 31(3), 259-279.

Lusardi, A., \& Mitchell, O. S. (2005). Financial literacy and planning: Implications for retirement wellbeing. Michigan Retirement Research Center Research Paper No. WP, 108.

Lusardi, A., \& Mitchell, O. S. (2007). Baby boomer retirement security: The roles of planning, financial literacy, and housing wealth. Journal of monetary Economics, 54(1), 205-224.

Lusardi, A., \& Mitchell, O. S. (2008). Planning and financial literacy: How do women fare? American Economic Review, 98(2), 413-417.

Lusardi, A., \& Mitchell, O. S. (2014). The economic importance of financial literacy: theory and evidence. Journal of Economic Literature, 52(1), 5-44.

Lusardi, A., Michaud, P. C., \& Mitchell, O. S. (2013). Optimal financial knowledge and wealth inequality, NBER Working Papers 18669, National Bureau of Economic Research.

Lusardi, A. \& Tufano, P. (2008). Debt literacy, financial experiences, and overindebtedness. Dartmouth Working Paper.

Modigliani, F., \& Brumberg, R.F.,. (1954). Utility analysis and the consumption function: An interpretation of cross-section data. In K. K. Kurihara, PostKeynesian Economics (pp 388-436). New Brunswick: Rutgers University Press

Moore, D. L. (2003). Survey of financial literacy in Washington State: Knowledge, behavior, attitudes, and experiences. Washington State Department of Financial 
Institutions.

Morck, R., Yeung, B., \& Yu, W. (2000). The information content of stock markets: why do emerging markets have synchronous stock price movements? Journal of Financial Economics, 58(1), 215-260.

Mottola, G. (2013). In our best interest: women, financial literacy, and credit card behavior. Numeracy, 6(2). doi: 10.5038/1936-4660.6.2.4

Pistor, K., \& Xu, C. (2005). Governing stock markets in transition economies: Lessons from China. American Law and Economics Review, 7(1), 184-210.

Puri, M., \& Robinson, D. T. (2007). Optimism and economic choice. Journal of Financial Economics, 86(1), 71-99.

Tsai, M., Dwyer, R. E., \& Tsay, R. (2014). Does financial assistance really assist? The impact of debt on wellbeing, health behavior and self-concept in Taiwan. Social Indicators Research. doi: 10.1007/s11205-014-0835-z

Utkus, S. P., \& Young, J. A. (2011). Financial Literacy and 401 (k) Loans. Financial Literacy: Implications for Retirement Security and the Financial Marketplace, 59.

Van Rooij, M., Lusardi, A., \& Alessie, R. (2011). Financial literacy and stock market participation. Journal of Financial Economics, 101(2), 449-472.

Vissing-Jørgensen, A. (2004). Perspectives on behavioral finance: Does "irrationality" disappear with wealth? Evidence from expectations and actions. In NBER Macroeconomics Annual 2003, Volume 18 (pp. 139-208). The MIT Press.

Vissing-Jørgensen, A., \& Attanasio, O. P. (2003). Stock-market participation, intertemporal substitution, and risk-aversion. American Economic Review, 93(2), 383-391.

Vlaev, I., \& Elliott, A. (2013). Financial well-being components. Social Indicators Research, 118(3), 1103-1123.

Wang, M., Lai, K. K., \& Yen, J. (2014). Private banking and wealth management industry in China. In China's Financial Markets: Issues and Opportunities (pp.205-206). Routledge.

Wang, X., \& Wen, Y. (2012). Housing prices and the high Chinese saving rate puzzle. China Economic Review, 23(2), 265-283.

Weber, E. U., \& Hsee, C. K. (1998), Cultural differences in risk perception, but cross-cultural similarities in attitudes towards perceived risk. Management Science, 44(9), 1205-1217.

Xia, T., Wang, Z., \& Li, K. (2014). Financial literacy overconfidence and stock 
market participation. Social Indicators Research, 119(3), 1233-1245.

Xiao, J. J., Chen, C., \& Chen, F. (2014). Consumer financial capability and financial satisfaction. Social Indicators Research, 118(1), 415-432.

Xie, Y., \& Hu, J. (2014). An introduction to the China Family Panel Studies (CFPS). Chinese Sociological Review, 47(1), 3-29.

Yoong, J. (2011). Financial illiteracy and stock market participation: Evidence from the RAND American Life Panel. In O. S. Mitchell and A. Lusardi (Eds.), Financial Literacy: Implications for Retirement Security and the Financial Marketplace (pp.76-97). Oxford and New York: Oxford University Press.

Zhao, X., \& Wang, S. (2007). Empirical study on Chinese mutual funds' performance. Systems Engineering - Theory \& Practice, 27(3), 1-11. 


\section{Appendix}

\section{Financial Literacy Questions in Chinese Survey of Consumer Finance (2014)}

The survey was conducted in Chinese. Questions are designed according to financial literacy questions in OECD consumer finance survey (Atkinson \& Messy, 2012) and Survey of Consumer Finances (SCF) in the U.S.. In this study, except for question 7, the questions are all come from the OECD consumer finance survey and Survey of Consumer Finances (SCF), only names and the numbers are changed. Question 7 is developed by the research team of China Center for Financial Economic.

1. One-year deposit interest rate: What is your estimation of one-year deposit interest rate?
(1) Below $1 \%$
(2) $1 \%-5 \%$
(3) $5 \%-10 \%$
(4) $10 \%$ and above (9) Do not know

2. Interest calculation: If you save 10,000 yuan in the bank for one year and the annual saving rate is $3 \%$, how much will get after one year?
(1) 10,300
(2) more than 10,300
(3) less than 10,300
(9) Do not know

3. Interest compounding: In the last question, if you continue saving the total amount you get for another year, how much will you get?
(1) 10,600
(2) more than 10,600
(3) less than 10,600
(9) Do not know

4. Inflation: If the annual saving interest rate is $3 \%$, and the inflation rate is $5 \%$. After one year, using the same amount of money, you will buy:

(1) more things than now (2) equal things with now (3) less things than now (9) Do not know 5. Time value of money: If Zhang inherits 100,000 yuan today, and Li will inherit 100,000 yuan after three years, who get more value from the inheritance?
(1) Zhang
(2) $\mathrm{Li}$
(3) They get the same value
(9) Do not know

6. Investment risk: Usually high return investment also have high risk.
(1) Right
(2) Wrong
(9) Do not know

7. Central bank: Which bank has the currency policy making function?
(1) Bank of China
(2) Industry and Commerce Bank of China
(3) People's Bank of China
(4) China Construction Bank
(9) Do not know

8. The risk of stock: Generally speaking, invest in one stock is less risky than invest in Equity funds.
(1) Right
(2) Wrong
(9) Do not know

9. The risk comparison: Generally speaking, which of the following asset is most risky?
(1) Bank saving
(2) Treasury bond
(3) Stock
(4) Mutual fund
(9) Do not know

10. The meaning of holding stocks: What does it mean if you buy stocks of a particular company? 
(1) No matter you hold the stock for a long term or a short term, you lend your money to the company

(2) No matter you hold the stock for a long term or a short term, you are the shareholder of the company

(3) You are shareholder when you hold for a long term, while you are only lenders if you only hold for a short while.

(4) All above are not right.

(9) Do not know

11. Mutual fund: Which of the following statement correctly describe mutual fund?

(1) Mutual fund with lower net worth will get higher performance in the future

(2) Generally speaking, a mutual fund could invest in several kinds of assets, such as stock and bonds

(3) Generally speaking, mutual fund can promise you a positive return base on past performance

(4) All above are not right.

(9) Do not know

12. Stock market: Which of the following statements correctly describe the core function of stock market?

(1) Stock market helps predict stock return

(2) Stock market helps increase stock price

(3) Stock market helps buyers and sellers of stocks

(4) All above are not right.

(9) Do not know 
Table 1 Household portfolio holding choice and percentage

\begin{tabular}{ccc}
\hline Household choice & Frequency & Percentage \\
\hline Participate into at least one asset & 522 & $13.36 \%$ \\
Stock holding & 397 & $10.16 \%$ \\
Fund holding & 216 & $5.53 \%$ \\
Only stock holding & 306 & $7.83 \%$ \\
Only fund holding & 125 & $3.56 \%$ \\
Holding both stock and fund & 91 & $2.33 \%$ \\
\hline
\end{tabular}

Source: Own calculation based on the financial asset section of Chinese Survey of Consumer Finance (2014) 
Table 2 Multivariate analysis of market participation: Probit results

\begin{tabular}{|c|c|c|c|c|}
\hline & $\begin{array}{c}\text { (1) } \\
\text { participation }\end{array}$ & $\begin{array}{c}\text { (2) } \\
\text { participation }\end{array}$ & $\begin{array}{l}\text { (3) } \\
\text { participation }\end{array}$ & $\begin{array}{l}\text { (4) } \\
\text { participation }\end{array}$ \\
\hline \multirow[t]{2}{*}{ FL } & $0.195^{* * *}$ & & $0.170 * * *$ & \\
\hline & $(0.0109)$ & & $(0.0141)$ & \\
\hline \multirow[t]{2}{*}{ financial_basic } & & $0.147^{* * *}$ & & $0.112 * * *$ \\
\hline & & $(0.0179)$ & & $(0.0210)$ \\
\hline \multirow[t]{2}{*}{ financial_adv } & & $0.262^{* * *}$ & & $0.258 * * *$ \\
\hline & & $(0.0231)$ & & $(0.0276)$ \\
\hline \multirow[t]{2}{*}{ age } & & & $0.110^{* * * *}$ & $0.113 * * *$ \\
\hline & & & $(0.0152)$ & $(0.0152)$ \\
\hline \multirow[t]{2}{*}{ agesquare } & & & $-0.000935^{* * *}$ & $-0.000953 * * *$ \\
\hline & & & $(0.000147)$ & $(0.000147)$ \\
\hline \multirow[t]{2}{*}{ logincome } & & & $0.361 * * *$ & $0.365 * * *$ \\
\hline & & & $(0.0474)$ & $(0.0474)$ \\
\hline \multirow[t]{2}{*}{ business owner } & & & $-0.199 * *$ & $-0.198 * *$ \\
\hline & & & $(0.0997)$ & $(0.100)$ \\
\hline \multirow[t]{2}{*}{ gender } & & & $-0.281 * * *$ & $-0.287 * * *$ \\
\hline & & & $(0.0642)$ & $(0.0644)$ \\
\hline \multirow[t]{2}{*}{ risk attitude } & & & $-0.263^{* * *}$ & $-0.255^{* * *}$ \\
\hline & & & $(0.0371)$ & $(0.0373)$ \\
\hline \multirow[t]{2}{*}{ Family size } & & & $-0.0920 * * *$ & $-0.0922 * * *$ \\
\hline & & & $(0.0270)$ & $(0.0271)$ \\
\hline \multirow[t]{2}{*}{ marriage status } & & & -0.119 & -0.112 \\
\hline & & & $(0.105)$ & $(0.105)$ \\
\hline \multirow{2}{*}{$\begin{array}{l}\text { Province Control variables } \\
\text { Living condition control }\end{array}$} & & & Yes & Yes \\
\hline & & & Yes & Yes \\
\hline \multirow[t]{2}{*}{ _cons } & $-2.346^{* * *}$ & $-2.264^{* * *}$ & $-7.814 * * *$ & $-7.881 * * *$ \\
\hline & $(0.0794)$ & $(0.0816)$ & $(0.702)$ & $(0.704)$ \\
\hline$N$ & 3906 & 3906 & 3654 & 3654 \\
\hline Pseudo $R^{2}$ & 0.126 & 0.129 & 0.276 & 0.281 \\
\hline
\end{tabular}

Standard errors in parentheses, $* \mathrm{p}<0.1, * * \mathrm{p}<0.05, * * * \mathrm{p}<0.01$. 
Table 3 Multivariate analysis of mutual fund holding and return: Probit results

(1)

(2)

\begin{tabular}{|c|c|c|}
\hline & fund_holding & fund_holding \\
\hline \multirow[t]{2}{*}{ FL } & $0.0542 *$ & \\
\hline & $(0.0289)$ & \\
\hline \multirow[t]{2}{*}{ financial_basic } & & 0.00492 \\
\hline & & $(0.0444)$ \\
\hline \multirow[t]{2}{*}{ financial_adv } & & $0.117 * *$ \\
\hline & & $(0.0522)$ \\
\hline \multirow[t]{2}{*}{ age } & 0.0234 & 0.0277 \\
\hline & $(0.0341)$ & $(0.0343)$ \\
\hline \multirow[t]{2}{*}{ agesquare } & -0.000146 & -0.000186 \\
\hline & $(0.000333)$ & $(0.000334)$ \\
\hline \multirow[t]{2}{*}{ logincome } & 0.0455 & 0.0429 \\
\hline & $(0.0888)$ & $(0.0888)$ \\
\hline \multirow[t]{2}{*}{ business owner } & 0.196 & 0.189 \\
\hline & $(0.195)$ & $(0.195)$ \\
\hline \multirow[t]{2}{*}{ gender } & $-0.226^{*}$ & $-0.237 *$ \\
\hline & $(0.122)$ & $(0.123)$ \\
\hline \multirow[t]{2}{*}{ risk attitude } & $0.213 * * *$ & $0.219 * * *$ \\
\hline & $(0.0772)$ & $(0.0773)$ \\
\hline \multirow[t]{2}{*}{ family size } & 0.0568 & 0.0572 \\
\hline & $(0.0608)$ & $(0.0608)$ \\
\hline \multirow[t]{2}{*}{ marriage status } & -0.224 & -0.230 \\
\hline & $(0.217)$ & $(0.218)$ \\
\hline Province Control variables & Yes & Yes \\
\hline Living condition control variables & Yes & Yes \\
\hline \multirow[t]{2}{*}{ _cons } & -1.642 & -1.634 \\
\hline & $(1.433)$ & $(1.433)$ \\
\hline$N$ & 509 & 509 \\
\hline Pseudo $R^{2}$ & 0.0614 & 0.0645 \\
\hline
\end{tabular}

Standard errors in parentheses, * $\mathrm{p}<0.1, * * \mathrm{p}<0.05$, *** $\mathrm{p}<0.01$ 
Table 4 Answer distribution of perceived financial literacy

\begin{tabular}{ccc}
\hline Answers & Frequency & Percent \\
\hline Level 1: Far above average & 31 & $0.79 \%$ \\
Level 2: Above average & 199 & $5.09 \%$ \\
Level 3:Average level & 1,552 & $39.73 \%$ \\
Level 4: Below average & 1,590 & $40.71 \%$ \\
Level 5:Far below average & 467 & $11.96 \%$ \\
Refuse to answer & 1 & $0.03 \%$ \\
Do not know & 66 & $1.69 \%$ \\
\hline
\end{tabular}

Source: Own calculation based on the financial literacy section of Chinese Survey of Consumer Finance (2014) 
Table 5 Effect of perceived financial literacy and overconfidence on stock holding: Probit result

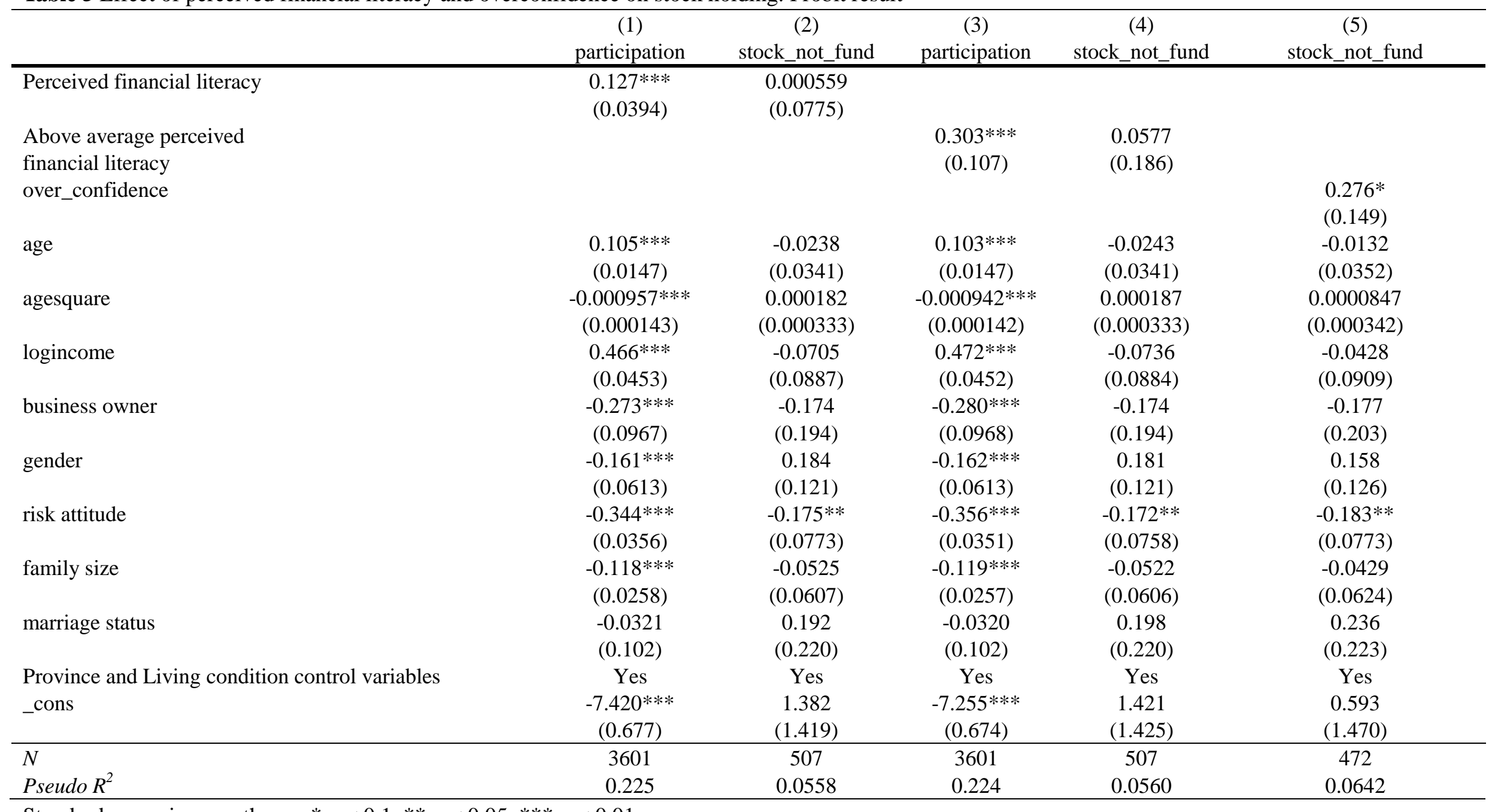

Standard errors in parentheses, $* \mathrm{p}<0.1, * * \mathrm{p}<0.05, * * * \mathrm{p}<0.01$ 
Table 6 Effect of financial literacy on positive return: Probit results

(1)

positive_return

positive_return

positive_return

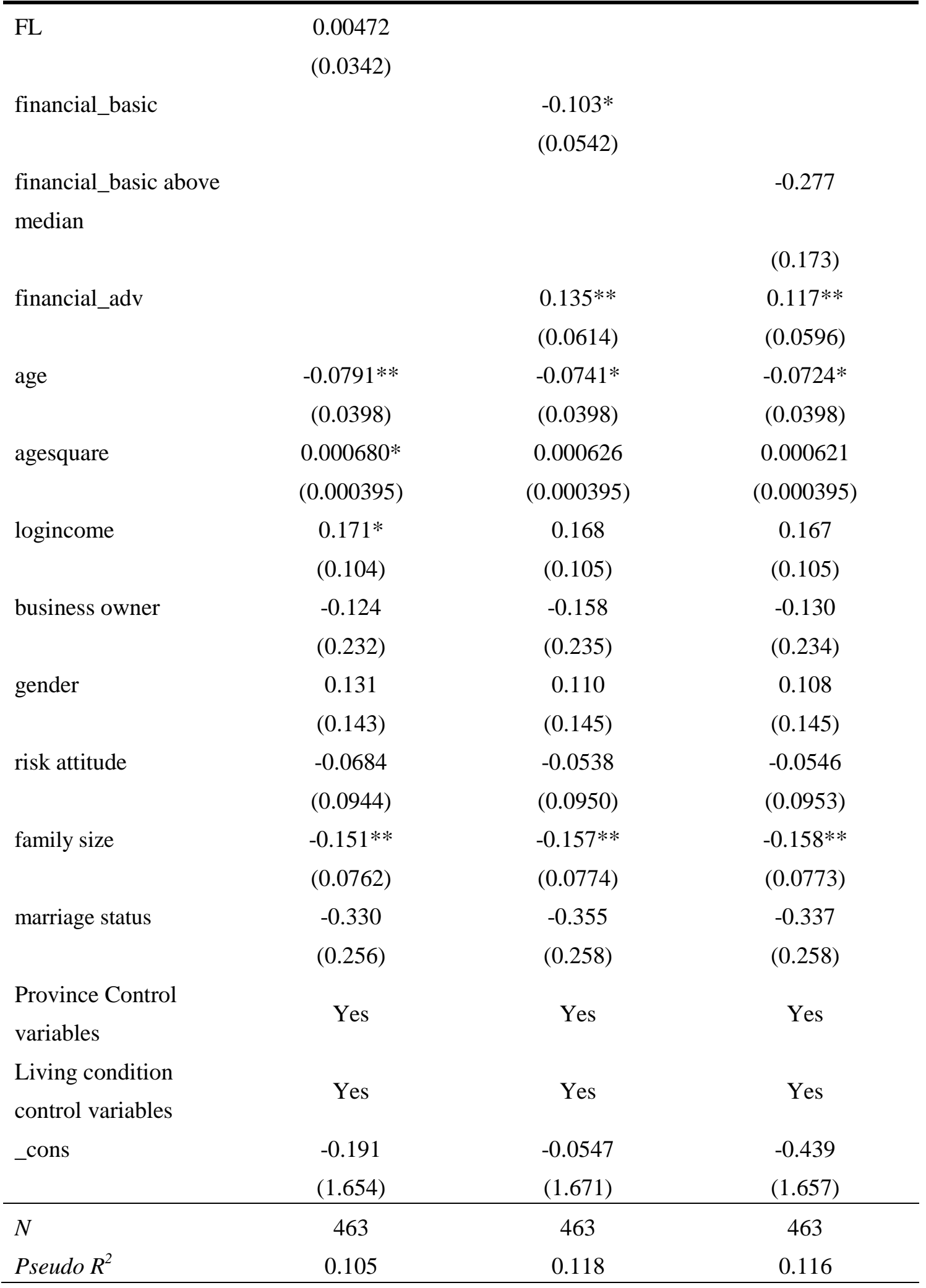

Standard errors in parentheses, $* \mathrm{p}<0.1, * * \mathrm{p}<0.05, * * * \mathrm{p}<0.01$ 
Table 7 Multivariate analysis of participation and mutual fund holding and return

(1)

participation
(2)

fund_holding

(3)

positive_return

\begin{tabular}{cccc}
\hline factor_basic & $0.290^{* * *}$ & -0.00474 & $-0.290^{*}$ \\
factor_adv & $(0.0560)$ & $(0.121)$ & $(0.148)$ \\
& $0.483^{* * *}$ & $0.213^{* *}$ & $0.237^{* *}$ \\
$\begin{array}{c}\text { Demographic Control } \\
\text { variables } \\
\begin{array}{c}\text { Province Control } \\
\text { variables }\end{array}\end{array}$ & Yes & $(0.0949)$ & $(0.111)$ \\
Living condition control & Yes & Yes & Yes \\
variables & Yes & Yes & Yes \\
cons & & Yes & Yes \\
& $-7.051^{* * *}$ & -1.437 & -0.308 \\
\hline$N$ & $(0.702)$ & $(1.424)$ & $(1.655)$ \\
\hline Pseudo $R^{2}$ & 3654 & 509 & 463 \\
\hline
\end{tabular}

Standard errors in parentheses, $* \mathrm{p}<0.1, * * \mathrm{p}<0.05, * * * \mathrm{p}<0.01$ 
Table 8 Multivariate analysis of market participation and portfolio choice: Robustness check: Exclude the top 5\%
(1)
(2)
(3)
(4)

participation participation fund_holding fund_holding

\begin{tabular}{lcccc}
\hline FL & $0.165^{* * *}$ & & $0.0571^{*}$ & \\
& $(0.0149)$ & & $(0.0318)$ & \\
financial_basic & & $0.111^{* * *}$ & & 0.000335 \\
& & $(0.0219)$ & & $(0.0478)$ \\
financial_adv & & $0.247 * * *$ & & $0.134 * *$ \\
& & $(0.0291)$ & & $(0.0582)$ \\
Demographic Control variables & Yes & Yes & Yes & Yes \\
Province Control variables & Yes & Yes & Yes & Yes \\
Living condition control & & & & Yes \\
variables & Yes & Yes & & Yes \\
_cons & $-8.109 * * *$ & $-8.249 * * *$ & -0.0480 & -0.272 \\
& $(0.845)$ & $(0.849)$ & $(1.842)$ & $(1.849)$ \\
\hline$N$ & 3454 & 3454 & 426 & 426 \\
$P s e u d o R^{2}$ & 0.265 & 0.269 & 0.0746 & 0.0789 \\
\hline
\end{tabular}

Standard errors in parentheses, $* \mathrm{p}<0.1, * * \mathrm{p}<0.05, * * * \mathrm{p}<0.01$ 
Fig. 1 Answers to financial literacy questions

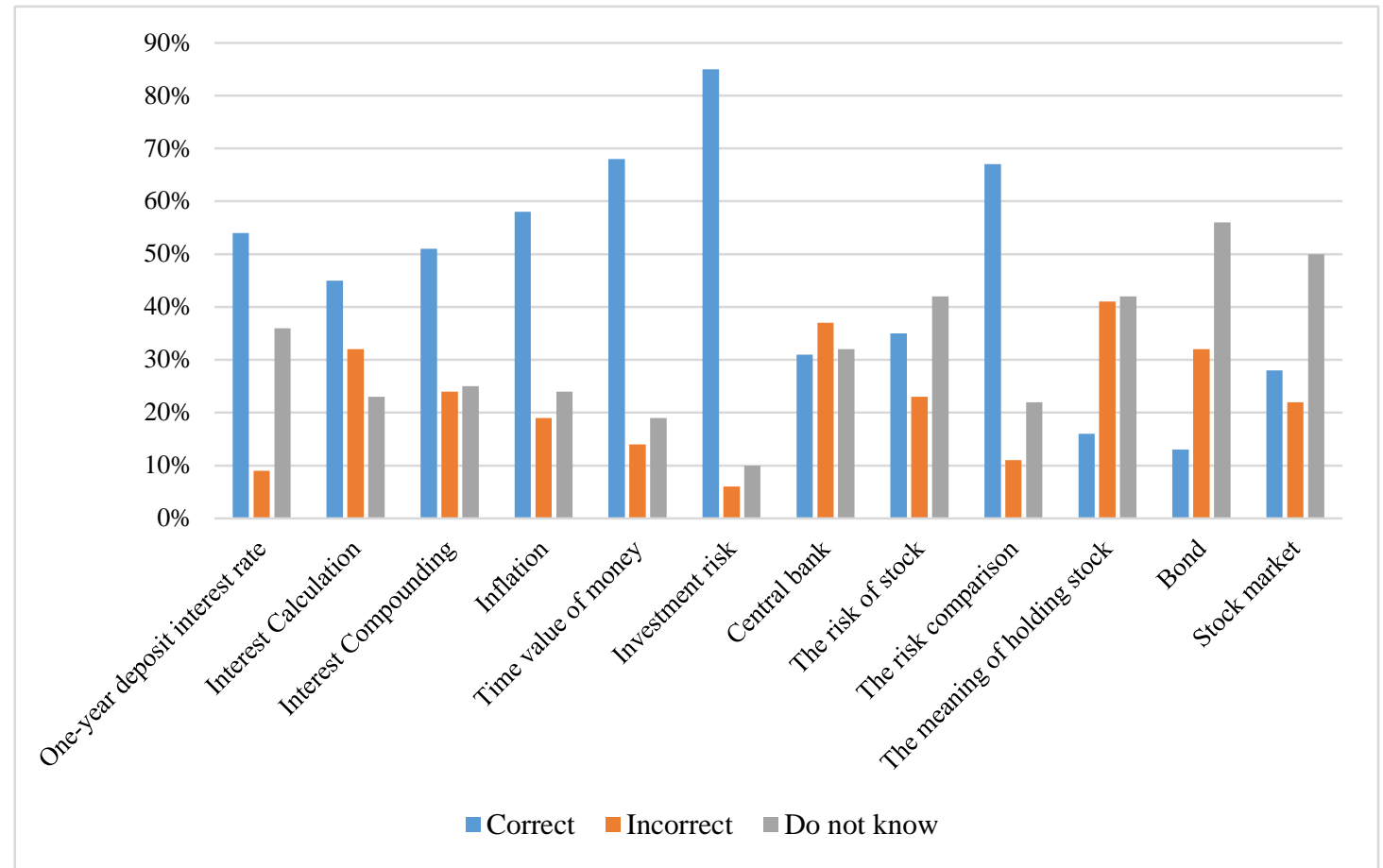

Source: Own calculation based on the financial asset section of Chinese Survey of Consumer Finance (2014) 